\title{
The Effects of COVID-19-related Driving Restrictions on Air Quality in an Industrial City
}

Aerosol and Air Quality Research

Special Issue:

Special Issue on COVID-19 Aerosol Drivers, Impacts and Mitigation (XVII)

\section{OPEN ACCESS}

Received: December 15, 2020

Revised: May 4, 2021

Accepted: May 5, 2021

${ }^{*}$ Corresponding Author:

aiymgul.kerimray@cfhma.kz

\section{Publisher:}

Taiwan Association for Aerosol Research

ISSN: $1680-8584$ print

ISSN: 2071-1409 online

cc) Copyright: The Author(s). This is an open access article distributed under the terms of the Creative Commons Attribution License (CC BY 4.0), which permits unrestricted use, distribution, and reproduction in any medium, provided the original author and source are cited.

\section{Daulet Assanov², Aiymgul Kerimray ${ }^{1 *}$, Birzhan Batkeyev ${ }^{3}$, Zhanna Kapsalyamova ${ }^{4}$}

${ }^{1}$ Al-Farabi Kazakh National University, Faculty of Chemistry and Chemical Technology, Center of Physical-Chemical Methods of Research and Analysis, Almaty, Kazakhstan

${ }^{2}$ Excellence Center "Veritas", D. Serikbayev East Kazakhstan Technical University, UstKamenogorsk, Kazakhstan

${ }^{3}$ International School of Economics, Kazakh-British Technical University, Almaty, Kazakhstan

${ }^{4}$ Department of Economics, 53 Kabanbay Batyr, Nazarbayev University, Nur-Sultan, Kazakhstan

\section{ABSTRACT}

To slow the spread of COVID-19, the state of emergency was announced in Kazakhstan on March 16, 2020. Ust-Kamenogorsk instituted COVID-19 lockdown measures on April 2, 2020. The restrictions reduced the flow of traffic in the city but did not have a major impact on the large industries and power plants. In the areas with a complex profile of emission sources, traffic restriction measures alone may hardly tackle serious air pollution. This natural experiment allowed us to test how the reduction in transport movement affects air quality in Ust-Kamenogorsk, as there is a tendency to hold transport as being a major cause of air pollution in Ust-Kamenogorsk. This study analyzes concentrations of four major air pollutants and meteorological parameters in Ust-Kamenogorsk from March 1 to May 15 in 2016-2020. Using the fixed effects model, we find that restrictions have decreased the levels of CO by 21-23 percent, increased the levels of TSP by 13-21 percent, and had no significant effect on $\mathrm{SO}_{2}$ and $\mathrm{NO}_{2}$ concentrations in the city. It implies that heavy pollution in the city with $\mathrm{SO}_{2}, \mathrm{NO}_{2}$, TSP are mainly caused by non-transportrelated sources.

Keywords: Air pollution, COVID-19 restrictions, Transport, Ust-Kamenogorsk

\section{INTRODUCTION}

Kazakhstan ranks $29^{\text {th }}$ in the list of the world's most polluted countries in 2019 (IQAir, 2019). Ambient air is polluted in most of the cities of Kazakhstan, but the most unfavorable situation is in the city of Ust-Kamenogorsk (Kenessary et al., 2019). Ust-Kamenogorsk is the administrative center of the East Kazakhstan region, with a population of 331 thousand as of 2019. It is located at the foothills of the Rudny Altai at the confluence of the Ulba and Irtysh rivers. In the east (10$15 \mathrm{~km}$ away), there are the western spurs of the Shanovsky ridge ( $800 \mathrm{~m}$ above sea level), and in the west, there are hilly plains. In the south-west and the south, there are northern spurs of the Kalbinsky ridge (up to $1500 \mathrm{~m}$ above the sea level). The average wind speed during the heating season is $2.3 \mathrm{~m} \mathrm{~s}^{-1}$, the average temperature ranges from $+20.2^{\circ} \mathrm{C}$ in July and $-15.8^{\circ} \mathrm{C}$ in January.

The city of Ust-Kamenogorsk is the center of mining and non-ferrous metallurgy of Kazakhstan. The city has lead-zinc, copper, titanium-magnesium, uranium, beryllium, and tantalum plants, such as Kazzink LLP, Ulba Metallurgical Plant JSC, Titanium Magnesium Plant, among others. Most of its industrial plants were constructed during the Soviet Union times in 1950-1960.

In 2019, Ust-Kamenogorsk was ranked as the most polluted city in Kazakhstan (Kazhydromet, 2020). Average annual concentrations of $\mathrm{TSP}, \mathrm{SO}_{2}, \mathrm{NO}_{2}$, and $\mathrm{CO}$ in 2019 were $109 \mu \mathrm{g} \mathrm{m}^{-3}, 90 \mu \mathrm{g} \mathrm{m}^{-3}$, $60 \mu \mathrm{g} \mathrm{m}^{-3}$ and $680 \mu \mathrm{g} \mathrm{m}^{-3}$, respectively (Kazhydromet, 2020).

Out of these four major pollutants, the city stands out with its abnormal levels of $\mathrm{SO}_{2}$ concentration. 
The annual average of $\mathrm{SO}_{2}$ concentration levels ranged from 65 to $118 \mu \mathrm{g} \mathrm{m}^{-3}$ from 2011 to 2019 . The city was also included in the list of global $\mathrm{SO}_{2}$ emission hotspots based on the OMI NASAAura Satellite database (Greenpeace, 2019). High $\mathrm{SO}_{2}$ concentration is found to be common in industrial locations that use sulphur-containing fuel (e.g., coal) and metals smelters (Zhao et al., 2019). There are wide health and environmental impacts of sulphur oxides and sulfate particles from both short and long-term exposures. High short-term exposures to $\mathrm{SO}_{2}$ can cause temporary difficulties in breathing, asthma attacks, and increased respiratory symptoms (Pan, 2011), and long-term exposures may lead to aggravation of existing heart disease and even premature death (Pan, 2011). Moreover, sulphur oxides contribute to the formation of acid rain, which causes damage to forests, crops, soils, lakes, and fish.

Some countries achieved substantial reductions in air pollution due to a range of policies and measures. Substantial declines in $\mathrm{SO}_{2}$ emissions were observed in the U.S. (U.S. EPA, 2019), Europe (Guerreiro et al., 2014; EEA, 2020), and China (Lin et al., 2012; Wang et al., 2018; Zhao et al., 2019) due to the stringent environmental regulations, technology improvements, and fuelswitching. Conversely, Kazakhstan has relatively weak environmental regulations and therefore major industrial cities including the city of Ust-Kamenogorsk continues to suffer from high air pollution levels (particularly with $\mathrm{SO}_{2}$ and TSP). Moreover, the incentives to substantially reduce the industrial emissions of air pollutants are ambiguous, as confirmed by the studies of Ecoservice (2019), and the Center of Environmental Security LLP, which tend to claim that transport is a major source of air pollution in Ust-Kamenogorsk.

To understand whether the transportation sector is indeed a major emitter in Ust-Kamenogorsk, we study the effect of COVID-19 lockdown measures on major air pollutants. The city instituted COVID-19 lockdown measures on April 2, 2020, seventeen days after a nation-wide state of emergency was announced in Kazakhstan. Based on the self-isolation index for the city, an indicator on the scale from 0 (no self-isolation) to 5 (complete self-isolation), the lockdown measures had an effect as seen from Fig. S1 in the Supplementary File. The Yandex Self-Isolation Index was launched in February 2020 and is based on the data from Yandex applications and services. It compares the current level of urban activity to the usual day before the epidemic (Source: https://datalens.yandex/covid19). The lockdown measures in Ust-Kamenogorsk included the closure of all public catering facilities and services, non-food stores and shopping centers, the transition of all educational institutions online; the transition of employees to remote work, except for employees of healthcare and strategic enterprises in power plants and large industries such as Kazzink LLP. Furthermore, the restriction on traffic in Ust-Kamenogorsk was in place from April 6 to May 16, 2020, which restricted the drivers from using their vehicles for more than three weekdays per week based on the last digit of a license plate. During the nights, all types of transport, except for social services, were banned. Such restrictions resulted in a substantial reduction in traffic (For instance, public transport circulation decreased by 70\%.), but did not have a significant impact on the activities of large industries such as Kazzink LLP and Ust-Kamenogorsk CHP. This policy feature allows us to assess the contribution of the transportation sector to air pollution in the city.

We contribute to the literature in two main respects. First, our study sheds light on the air quality in the Ust-Kamenogorsk city using a high spatial and temporal resolution dataset. Despite extremely high pollution levels in Ust-Kamenogorsk city, to the best of our knowledge, none of the studies provided an in-depth analysis of the air quality in Ust-Kamenogorsk. Previous studies explore air quality in cities of Kazakhstan and of the Central Asian region in general. As such they focused on the assessment of air quality mainly in urban cities of Kazakhstan such as Almaty (Kerimray et al., 2020) and Nur-Sultan (Kerimray et al., 2018). Darynova et al. (2020) analyzed satellite observations for tropospheric $\mathrm{SO}_{2}$ and $\mathrm{HCHO}$ in urban locations (Almaty, Nur-Sultan, Shymkent) and industrial cities (Atyrau and Ekibastuz). Kenessary et al. (2019) evaluated air pollution levels in 26 cities of Kazakhstan and found "extremely high" chronic effects risk due to heavy metals exposure in Ust-Kamenogorsk.

Second, this study further contributes to the literature that studies the effects of the COVID19 lockdown measures on the environment. Overall, the environmental effects of COVID-19 related lockdown measures sparked a genuine interest in the literature as it represents a huge natural experiment (Helm, 2020). The reduction in air pollution due to COVID-19 lockdowns was documented in several studies, such as for Istanbul (Şahin, 2020), Barcelona (Tobías et al., 2020), 
mainland China (Chen et al., 2020), and Malaysia (Ash'aari et al., 2020). Analysis by pollutant type shows that the lockdown measures do not affect pollutants uniformly. For instance, some studies found an increase in $\mathrm{O}_{3}$ (Kerimray et al., 2020; Li and Tartarini, 2020; Sharma et al., 2020) and $\mathrm{SO}_{2}$ (Kerimray et al., 2020; Sharma et al., 2020). The evidence suggests the effects of lockdown measures are largely driven by the pertinent features related to the structure of the economies, emission intensity of the industrial and transportation sectors.

Most studies on COVID-19 lockdown impacts focused on large urban cities, a very few studies cover industrial locations. For instance, He et al. (2020) found that the effects of lockdown on air quality in China were larger in industrial cities. On the other hand, Ash'aari et al. (2020) reported lower changes in industrial stations of Malaysia compared to urban locations. Thus, the impact of COVID-19 lockdown restriction measures on the air quality could be different, especially in the area with a complex profile of emissions sources.

Our study applies the fixed-effects model to the data from Ust-Kamenogorsk. This is the first study that uses a rigorous methodology for a large industrial and heavily polluted city in Kazakhstan with a complex profile of emissions sources. We focus on the ambient concentrations of four major pollutants, namely, $\mathrm{SO}_{2}, \mathrm{NO}_{2}, \mathrm{TSP}$, and $\mathrm{CO}$, before and after the COVID-19 related lockdown restrictions covering the same period from March 1 to May 15 for five years, from 2016 to 2020.

\section{DATA AND METHODOLOGY}

\subsection{Data Description}

For empirical analysis, we employ the data from two sources: (i) the air pollution data is collected from the National Air Quality Monitoring Network (NAQMN) by Kazhydromet, the National Hydrometeorological Service of Kazakhstan. The Kazhydromet laboratory in Ust-Kamenogorsk is accredited by ILAC (International Laboratory Accreditation Cooperation, https://ilac.org/), with the measurement results recognized internationally; (ii) the weather data is collected from the online resource www.rp5.kz that collects weather information for a variety of locations worldwide, including Kazakhstan, and provides weather forecasts for 6 days. Fig. 1 illustrates the locations of five NAQMN air quality monitoring stations in Ust-Kamenogorsk with the manual method of data collection.

The NAQMN monitoring stations are the rooms with sampling equipment consisting of an intake pipe and an aspirator. The stations collect air quality data four times a day at 1 AM, 7 AM, $1 \mathrm{PM}$, and $7 \mathrm{PM}$. At the indicated time, employees of Kazhydromet take air samples for gas analysis $\left(\mathrm{NO}_{2}, \mathrm{SO}_{2}, \mathrm{CO}\right)$ in special tubes. The selected air samples are transported to the laboratory of Kazhydromet. A TSP sample is taken onto a paper filter by the gravimetric method. Kazhydromet analyses the air samples for $\mathrm{NO}_{2}, \mathrm{SO}_{2}, \mathrm{CO}$, and weights the TSP samples in the laboratory setting. The concentration of dust determines the TSP mass. The measurement results are available within two hours on the Kazhydromet interactive monitoring map (http://apps.kazhydromet.kz: 3838/app_dem_visual/). Concentrations of pollutants are determined according to the methods approved in Kazakhstan:

- TSP concentration is determined according to the Standard of the Republic of Kazakhstan "ST RK 1957-2010" by gravimetric method (https://www.egfntd.kz/rus/tv/343447.html?sw_gr=$1 \&$ sw_str=\&sw_sec=24\#gallery-18). A certain volume of air is sucked through a filter paper with a known mass. After sampling, the filter is weighed again. The difference in filter mass is the amount of dust trapped. Based on the volume of sucked in air, the concentration is determined.

- $\mathrm{SO}_{2}$ concentration in the atmosphere is determined by the photometric method according to the Guidance Document №52.04.822-2015 (https://files.stroyinf.ru/Index2/1/4293755/429 3755211.htm). $\mathrm{SO}_{2}$ from the atmospheric air is captured by a film chemisorbant based on sodium tetrachloromercurate. Then the concentration of $\mathrm{SO}_{2}$ is determined in the laboratory on a photoelectric calorimeter due to its interaction with formaldehyde and pararosaniline or fuchsin.

- $\mathrm{NO}_{2}$ concentration is determined by the photometric method according to the methodology №52.04.792-2014 (https://files.stroyinf.ru/Index2/1/4293759/4293759047.htm). $\mathrm{NO}_{2}$ from the atmospheric air is captured by a film chemisorbant based on potassium iodide. Then the concentration of $\mathrm{NO}_{2}$ is determined in the laboratory on a photoelectric calorimeter due to its interaction with sulfanilic acid and I-naphthylamine. 


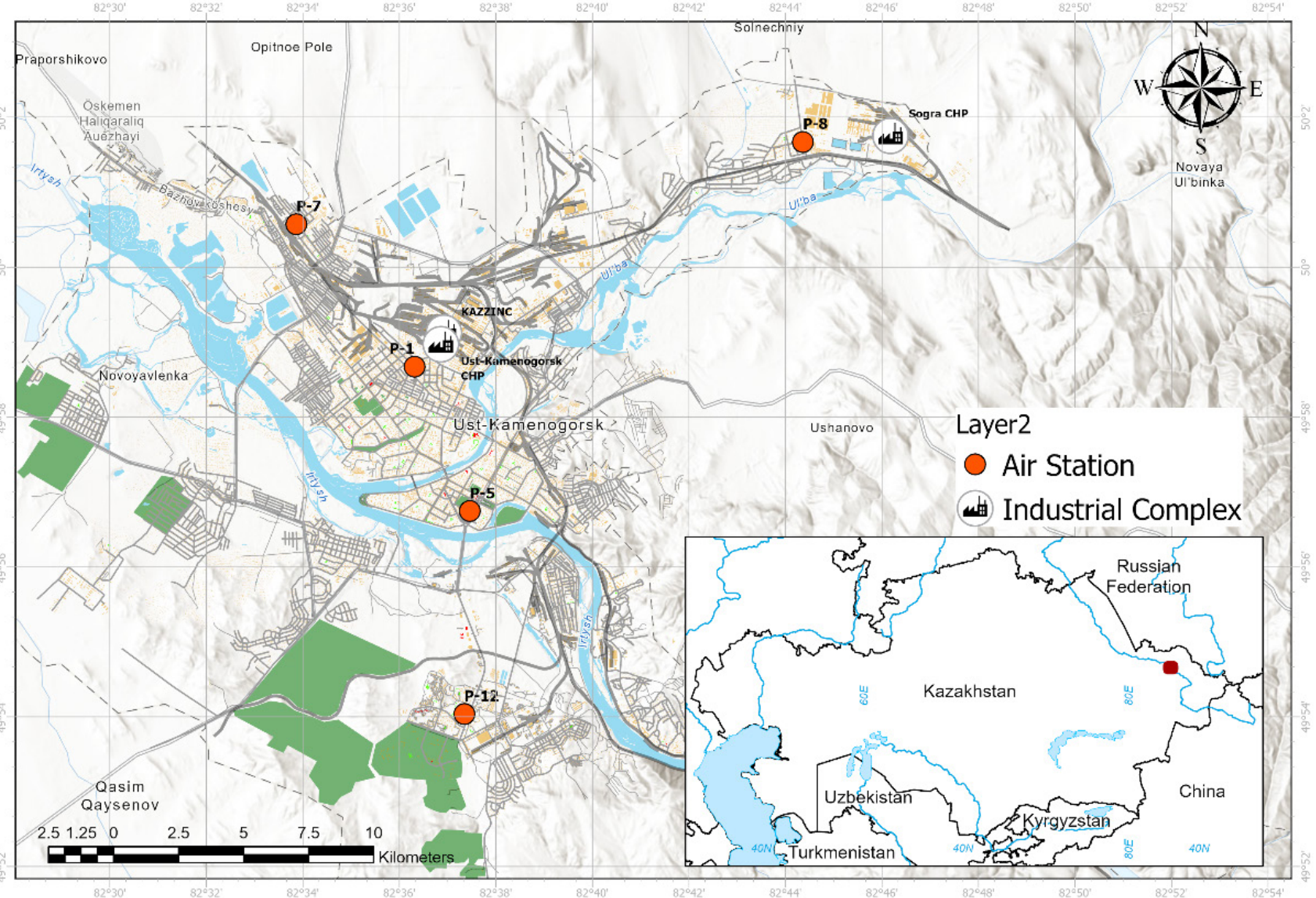

Fig. 1. Map of Ust-Kamenogorsk with the location of the air quality monitoring stations, CHP and industry.

- CO concentration in the atmosphere is determined by the portable gas analyzer "GANK-4» (https://www.gank4.ru/) according to the Standard of the Republic of Kazakhstan №2.3022014 "Measurement procedure determination of the mass concentration of harmful substances in the atmospheric air, in the air of the working area, in the industrial emissions by the gas analyzer". The gas analyzer has an electrochemical sensor to determine the CO concentration.

In Kazakhstan, only the results of measurements by accredited laboratories are recognized. The East Kazakhstan branch of the RSE "Kazhydromet" is an accredited laboratory in Kazakhstan. The National Center for Expertise and Certification (https://naceks.kz/services/metrologiya/) supervises the activities of laboratories and conducts interlaboratory comparison measurements in the event of a dispute between accredited laboratories.

The web resource www.rp5.kz that is operated by the Raspisaniye Pogodi Ltd., Russia from 2004 collects the actual weather data from the international data exchange, NOAA, the United States. The 6-day weather forecasts, available at www.rp5.kz, are prepared by the Met Office, the United Kingdom. We used www.rp5.kz weather resource because the actual weather data is reported 8 times a day and could be matched with the NAQMN pollution data, based on the nearest sampling hour. We used the weather data on hourly temperature, humidity, precipitation, wind speed, and wind direction for our empirical model.

The pollution and weather data were collected for the March 1 to May 15 for the years between 2016 and 2020. This sample period is chosen to control for yearly variation (Davis, 2008; Kerimray et al., 2020) as well as pre- and during COVID-19 lockdown dates.

\subsection{Descriptive Statistics}

Table 1 reports mean values for four air pollutants, in particular, $\mathrm{CO}, \mathrm{NO}_{2}$, $\mathrm{SO}_{2}$, and TSP. The results are presented for two time periods, March 1-April 1 vs. April 2-May 15. March 1-April 1, 2020, defines the pre-lockdown period, while April 2-May 15, 2020, defines the lockdown period. 
Table 1. Mean values of air pollutants*.

\begin{tabular}{|c|c|c|c|c|c|c|c|c|}
\hline \multirow[b]{2}{*}{ Year } & \multicolumn{2}{|c|}{$\mathrm{CO}$} & \multicolumn{2}{|c|}{$\mathrm{NO}_{2}$} & \multicolumn{2}{|c|}{$\mathrm{SO}_{2}$} & \multicolumn{2}{|c|}{ TSP } \\
\hline & $\begin{array}{l}\text { March 1- } \\
\text { April 1 }\end{array}$ & $\begin{array}{l}\text { April 2- } \\
\text { May } 15\end{array}$ & $\begin{array}{l}\text { March 1- } \\
\text { April 1 }\end{array}$ & $\begin{array}{l}\text { April 2- } \\
\text { May } 15\end{array}$ & $\begin{array}{l}\text { March 1- } \\
\text { April 1 }\end{array}$ & $\begin{array}{l}\text { April 2- } \\
\text { May } 15\end{array}$ & $\begin{array}{l}\text { March 1- } \\
\text { April 1 }\end{array}$ & $\begin{array}{l}\text { April 2- } \\
\text { May } 15\end{array}$ \\
\hline \multirow[t]{2}{*}{2016} & 758.33 & 460.96 & 73.04 & 50.74 & 67.74 & 59.34 & 166.88 & 81.61 \\
\hline & (844.94) & (752.71) & (52.55) & (39.39) & (18.84) & (16.6) & (133.24) & (78.06) \\
\hline \multirow[t]{2}{*}{2017} & 866.67 & 508.25 & 81.08 & 66.92 & 109.29 & 72.87 & 200.42 & 74.76 \\
\hline & (1012.93) & (870.58) & (73.57) & (58.79) & (57.49) & (24.58) & (173.39) & (86.79) \\
\hline \multirow[t]{2}{*}{2018} & 556.25 & 385.23 & 59.25 & 63.32 & 75.44 & 72.25 & 107.66 & 71.48 \\
\hline & (970.6) & $(712.64)$ & (27.63) & $(37.82)$ & (38.27) & (30.07) & (120.59) & (101.15) \\
\hline \multirow[t]{2}{*}{2019} & 773.91 & 341.43 & 93.8 & 43.09 & 90.64 & 66.18 & 164.78 & 55.71 \\
\hline & (961.67) & (696.81) & (48.33) & $(30.84)$ & (73.41) & (19.21) & $(164.96)$ & $(85.64)$ \\
\hline \multirow[t]{2}{*}{2020} & 784.78 & 314.66 & 75.7 & 53.78 & 95.22 & 88.47 & 96.74 & 54.6 \\
\hline & (1041.3) & (517.45) & (39.61) & (31.84) & (41.19) & $(56.05)$ & (96.17) & (71.02) \\
\hline
\end{tabular}

${ }^{*}$ Standard deviations are reported in parenthesis.

Table 2. Descriptive Statistics: Weather variables* .

\begin{tabular}{|c|c|c|c|c|c|c|c|c|}
\hline \multirow[b]{2}{*}{ Year } & \multicolumn{2}{|c|}{ Temperature $\left({ }^{\circ} \mathrm{C}\right)$} & \multicolumn{2}{|c|}{ Humidity (\%) } & \multicolumn{2}{|c|}{ Precipitation (mm) } & \multicolumn{2}{|c|}{ Wind speed $\left(\mathrm{m} \mathrm{s}^{-1}\right)$} \\
\hline & $\begin{array}{l}\text { March 1- } \\
\text { April } 1\end{array}$ & $\begin{array}{l}\text { April 2- } \\
\text { May } 15\end{array}$ & $\begin{array}{l}\text { March 1- } \\
\text { April 1 }\end{array}$ & $\begin{array}{l}\text { April 2- } \\
\text { May } 15\end{array}$ & $\begin{array}{l}\text { March 1- } \\
\text { April } 1\end{array}$ & $\begin{array}{l}\text { April 2- } \\
\text { May } 15\end{array}$ & $\begin{array}{l}\text { March 1- } \\
\text { April 1 }\end{array}$ & $\begin{array}{l}\text { April 2- } \\
\text { May } 15\end{array}$ \\
\hline \multirow[t]{2}{*}{2016} & -2.21 & 9.83 & 80.33 & 64.13 & & & 2.21 & 2.97 \\
\hline & $(6.74)$ & (3.10) & (9.01) & $(12.07)$ & & & (1.19) & (1.25) \\
\hline \multirow[t]{2}{*}{2017} & -5.22 & 10.98 & 72.48 & 59.26 & & & 2.54 & 2.44 \\
\hline & (7.43) & (6.49) & (12.39) & $(12.41)$ & & & (2.04) & $(1.60)$ \\
\hline \multirow[t]{2}{*}{2018} & -1.78 & 8.40 & 74.52 & 66.70 & 0.92 & 0.50 & 3.10 & 3.55 \\
\hline & (7.15) & (4.99) & (8.56) & $(13.60)$ & $(1.75)$ & $(0.86)$ & $(2.35)$ & $(1.80)$ \\
\hline \multirow[t]{2}{*}{2019} & -0.16 & 8.46 & 72.99 & 60.85 & 0.04 & 0.29 & 1.24 & 2.10 \\
\hline & $(4.84)$ & (4.77) & (8.05) & $(12.80)$ & $(0.12)$ & $(0.62)$ & (1.35) & (1.89) \\
\hline \multirow[t]{2}{*}{2020} & -2.24 & 12.94 & 64.68 & 53.46 & 0.13 & 0.17 & 2.54 & 2.76 \\
\hline & (5.12) & $(6.01)$ & (10.67) & $(15.73)$ & $(0.38)$ & $(0.45)$ & $(1.27)$ & (1.37) \\
\hline
\end{tabular}

${ }^{*}$ Standard deviations are reported in parenthesis.

The descriptive statistics are reported for both periods in years between 2016 and 2020 to show variations over the years. Table 1 shows that the average concentration of all pollutants is noticeably lower in April and May, compared to March, most likely due to the end of the heating period, around April 19.

Given that Ust-Kamenogorsk CHP uses coal for heating and electricity, the ending of the the heating period corresponds to the lower use of coal for combustion purposes and hence lower emissions. The concentration of TSP consistently declines over the years. The concentration of all pollutants declines in 2018 and rebounds in 2019 and 2020 for all pollutants, except for TSP. The concentration of $\mathrm{CO}$ in the lockdown period declines compared to the pre-lockdown period and the same periods in previous years. CO emissions largely stem from the transportation sector, and their decline might be attributed mainly to the driving restrictions introduced on April 2, 2020. The concentration of $\mathrm{NO}_{2}$ in the atmosphere in the lockdown period is notably lower than in the same period between 2016 and 2018 but is higher than in 2019. The concentration of $\mathrm{SO}_{2}$ in the lockdown period is higher than in the same period in other years.

Table 2 shows the summary statistics for weather variables. During the period between March 1 and May 15, the average temperature is $5.23^{\circ} \mathrm{C}$, humidity is $65.85 \%$, precipitation is $0.22 \mathrm{~mm}$, and wind speed is $2.63 \mathrm{~m} \mathrm{~s}^{-1}$ on average for all years. There is an increase in temperatures between two time periods of about $10^{\circ} \mathrm{C}$ accompanied with a drop in humidity in all years. The changes in the wind speed vary over the years, while precipitation falls between two periods in 2018 and increases in 2019 and 2020.

During this period, the wind speed in Ust-Kamenogorsk was within 1-4 $\mathrm{m} \mathrm{s}^{-1}$ (Fig. 2). That 


\section{Wind Rose - Ust-Kamenogorsk}

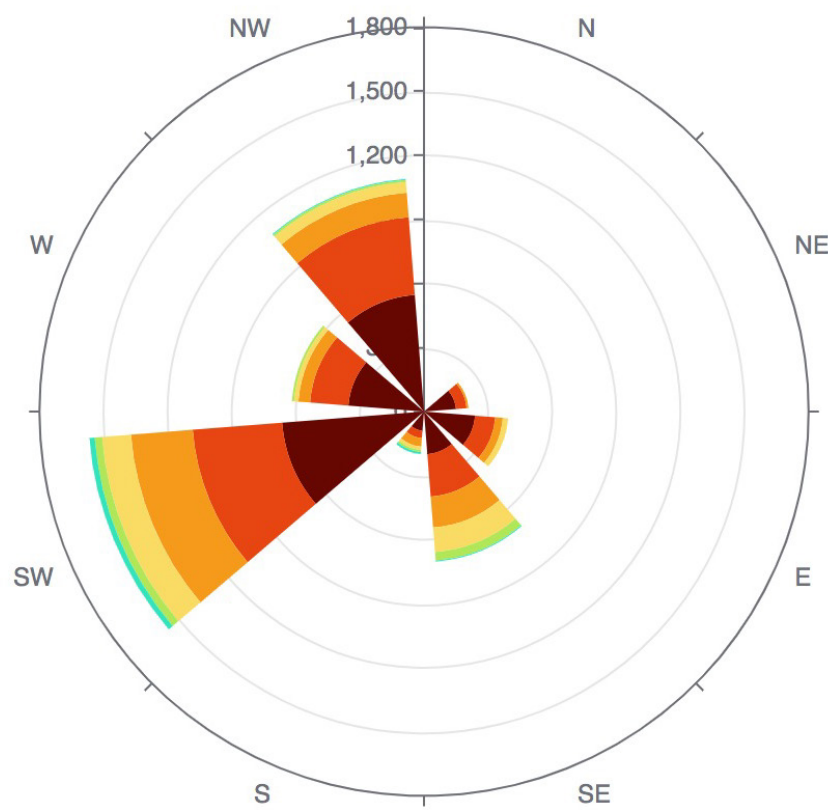

$1-2 \mathrm{~m} / \mathrm{s}$ $3-4 \mathrm{~m} / \mathrm{s}$ $5-6 \mathrm{~m} / \mathrm{s}$ $7-8 \mathrm{~m} / \mathrm{s}$ $9-10 \mathrm{~m} / \mathrm{s}$ $>=11 \mathrm{~m} / \mathrm{s}$

Fig. 2. Wind rose map for Ust-Kamenogorsk city for 2016-2020 years.

corresponds to the light air on the Beaufort scale. The low wind speed is due to the geographical location of the city. The predominant direction was southwest.

\subsection{The Model}

The baseline empirical model is given by the following equation:

$\ln \left(y_{s t}\right)=\alpha_{0}+\alpha_{1}$ Lockdown $_{t}+\alpha_{2} X_{s t}+\mu_{s}+\lambda_{t}+u_{s t}$

where $y_{s t}$ is the pollution level of sensor $s$ at a given date and time $t$ in logs, Lockdown is a dummy variable which equals 1 from the lockdown period in Ust-Kamenogorsk from April 2 to May 15, 2020, $X_{s t}$ includes weather regressors such as temperature, precipitation, wind speed, humidity and wind directions at a given time on a given date, $\mu_{s}$ is the sensor fixed effect, $\lambda_{t}$ is the time fixed effect, which constitutes time, day, month, year, and $u_{s t}$ is the error term. The inclusion of weather variables and time fixed effects is widely used in the air pollution literature (Davis, 2008; Chen and Whalley, 2012).

The coefficient of interest, $\alpha_{1}$, shows the percentage effect of COVID-19 lockdown on air pollution. Since spatial correlation could be an issue in such models, the standard errors were corrected using the Driscoll-Kraay method (Driscoll and Kraay, 1998; Hoechle, 2007). For robustness checks, some specifications include the weather variables that are squared and cubed.

\section{RESULTS AND DISCUSSION}

\subsection{Analysis of Air Pollution}

Table 3 shows ambient air quality standards for Kazakhstan and WHO (2006). WHO air guidelines recommend an average 24-hour limit value for $\mathrm{SO}_{2}$ at $20 \mu \mathrm{g} \mathrm{m}^{-3}$, the average annual limit for $\mathrm{NO}_{2}$ at $40 \mu \mathrm{g} \mathrm{m}^{-3}$ (WHO, 2006). In Kazakhstan and many post-Soviet countries "maximum one-time" limit value is used for $\mathrm{PM}_{10}, \mathrm{PM}_{2.5}, \mathrm{SO}_{2}, \mathrm{NO}_{2}$, while WHO does not establish a "maximum onetime" limit for those pollutants. The maximum one-time limit in Kazakhstan is provided as 
Table 3. Maximum allowable concentration (MAC) in Russia, Belarus, Kazakhstan, and WHO.

\begin{tabular}{|c|c|c|c|c|c|c|c|c|c|c|c|}
\hline \multirow{2}{*}{ Pollutant } & \multicolumn{3}{|c|}{ Maximum one-time MAC $\left(\mu \mathrm{g} \mathrm{m}^{-3}\right)$} & \multicolumn{4}{|c|}{ Average daily MAC $\left(\mu \mathrm{g} \mathrm{m}^{-3}\right)$} & \multicolumn{4}{|c|}{ Average annual MAC $\left(\mu \mathrm{g} \mathrm{m}^{-3}\right)$} \\
\hline & Kazakhstan & Russia & Belarus & Kazakhstan & Russia & Belarus & WHO & Kazakhstan & Russia & Belarus & WHO \\
\hline TSP & 500 & 500 & 300 & 150 & 150 & 150 & - & - & - & 100 & - \\
\hline $\mathrm{PM}_{10}$ & 300 & - & 150 & 60 & - & 50 & 50 & - & - & 40 & 20 \\
\hline $\mathrm{PM}_{2.5}$ & 160 & - & 65 & 35 & - & 25 & 25 & - & - & 15 & 10 \\
\hline $\mathrm{SO}_{2}$ & 500 & 500 & 500 & 50 & 50 & 200 & 20 & - & - & 50 & - \\
\hline $\mathrm{CO}$ & 5000 & 5000 & 5000 & 3000 & 3000 & 3000 & & - & - & 500 & \\
\hline $\mathrm{NO}_{2}$ & 200 & 85 & 250 & 40 & 40 & 100 & - & - & - & 40 & 40 \\
\hline
\end{tabular}

Source: Maximum Allowable Concentrations (MPC) of Pollutants in the Atmospheric Air of Populated Areas (1998); On Approval and Enforcement Maximum Permissible Standards Pollutant Concentrations in Atmospheric Air and Approximately Safe Levels Exposure to Pollutants in Atmospheric Air Populated Points and Places of Mass Rest Population and Recognition the Strength (2016); About the Approval of Hygienic Standards for Atmospheric Air in Urban and Rural Settlements (2015).

$500 \mu \mathrm{g} \mathrm{m}^{-3}$ for $\mathrm{SO}_{2}$ and $200 \mu \mathrm{g} \mathrm{m}^{-3}$ for $\mathrm{NO}_{2}$ (Ministry of the national economy of the Republic of Kazakhstan, 2015). Annual limit values are not established in Kazakhstan. WHO establishes limit values for $\mathrm{PM}_{2.5}$ and $\mathrm{PM}_{10}$, and does not establish limit values for TSP, which is measured in Kazakhstan. For this reason, TSP values were compared with national air quality standards.

Results show that Ust-Kamenogorsk is a heavily polluted city, and particularly, has high $\mathrm{SO}_{2}$ emissions. Daily WHO limit value for $\mathrm{SO}_{2}\left(20 \mu \mathrm{g} \mathrm{m}^{-3}\right)$ was exceeded on all days and lockdown period was not an exception. Average $\mathrm{SO}_{2}$ concentration was $95 \mu \mathrm{g} \mathrm{m}^{-3}$ and $88 \mu \mathrm{g} \mathrm{m}^{-3}$ during the pre-lockdown (March 1-April 1, 2020) and lockdown periods (April 2-May 15, 2020), respectively. The $\mathrm{SO}_{2}$ concentrations were substantially higher in Ust-Kamenogorsk $\left(88 \mu \mathrm{g} \mathrm{m}^{-3}\right)$, during the lockdown, relative to other parts of the world, such as Delhi $\left(12 \mu \mathrm{g} \mathrm{m}^{-3}\right)$, Mumbai $\left(29 \mu \mathrm{g} \mathrm{m}^{-3}\right)$ (Bedi et al., 2020), Istanbul (1.2-4.7 $\mu \mathrm{g} \mathrm{m}^{-3}$ ) (Şahin, 2020), Singapore (2.2-7.1 $\mu \mathrm{g} \mathrm{m}^{-3}$ ) (Li and Tartarini, 2020), and Beijing-Tianjin-Hebei region in China $\left(10 \mu \mathrm{g} \mathrm{m}^{-3}\right.$ ) (Chen et al., 2020).

Analysis of data for the previous years depicted that $\mathrm{SO}_{2}$ concentration levels were reduced annually in April compared to March (2016-2019) by 4-33\% (Table 1). These seasonal reductions of $\mathrm{SO}_{2}$ were lower compared to the reductions of TSP, which declined annually by $34-66 \%$ in April compared to March (Table 1). This indicates that $\mathrm{SO}_{2}$ pollution is caused not only by heating but potentially by other sources (e.g., metallurgy industries).

Average $\mathrm{NO}_{2}$ concentrations were $76 \mu \mathrm{g} \mathrm{m}^{-3}$ and $54 \mu \mathrm{g} \mathrm{m}^{-3}$ during the pre-lockdown (March 1-April 1, 2020), and lockdown periods (April 2-May 15, 2020), respectively. Average TSP concentration was $97 \mu \mathrm{g} \mathrm{m}^{-3}$ and $55 \mu \mathrm{g} \mathrm{m}^{-3}$ during the pre-lockdown (March 1-April 1, 2020), and lockdown periods (April 2-May 15, 2020), respectively. In the pre-lockdown period (March 1-April 1, 2020), only 4 days were exceeding the national daily TSP limit $\left(150 \mu \mathrm{g} \mathrm{m}^{-3}\right)$. During the lockdown period (April 2-May 15, 2020), emissions were within the daily TSP limit $\left(150 \mu \mathrm{g} \mathrm{m}^{-3}\right)$.

The Ust-Kamenogorsk metallurgical complex Kazzinc LLP is a major emitter of industrial emissions. COVID-19 lockdown did not disrupt the production processes of Kazzinc LLP due to its social significance for the population. According to the environmental permit document of Kazzinc LLP, the amount of "maximum permissible emissions" per year include 17,600 tons of $\mathrm{SO}_{2}, 8,500$ tons of $\mathrm{CO}, 260$ tons of $\mathrm{NO}_{2}$ and 203 tons of solid particles (Department of Ecology of East-Kazakhstan Region, 2017). Existing emissions permitting systems, monitoring, and enforcement of industrial emissions are weak, hence industrial enterprises may formally comply with environmental legislation.

"Ust-Kamenogorsk CHP" is another major industrial source of emissions in the city, with annual consumption of 1.5 million tons of coal. According to the State Environmental Review Report, the amount of "maximum permissible emissions" per year at the CHP included 4,500 tons of $\mathrm{NO}_{2}$, 9,200 tons of $\mathrm{SO}_{2}, 180$ tons of $\mathrm{CO}, 3,000$ tons of ash dust (Department of Ecology of EastKazakhstan Region, 2018). The second power plant named "Sogrinsk CHP" has an annual consumption of coal of up to 360 thousand tons per year (Department of Ecology of East-Kazakhstan Region, 2016). In the winter-time, coal-fired CHPs increase their coal consumption, due to additional heat generation. None of those power plant plants have advanced emissions controls, such as filters for $\mathrm{PM}$ collection and desulphurization for $\mathrm{SO}_{2}$ removal. Emissions at coal-fired power plants exceed the limit values for Europe for solid particles by a factor of 10 , for $\mathrm{NO}_{2}$ by more than $20 \%$, 
and for $\mathrm{SO}_{2}$ by a factor of 2.5 (Concept for the transition of the Republic of Kazakhstan to a "green economy", 2013). Additionally, the lack of systems for the continuous automated monitoring of emissions prevents the real emissions of enterprises from being tracked. In contrast, China introduced "ultra-low" emission standards for coal-fired power plants in 2014; by 2017, almost all coal-fired power plants in China installed $\mathrm{NO}_{x}$ and $\mathrm{SO}_{2}$ control devices (Tang et al., 2019). Between 2014 and 2017, China's annual power emissions of $\mathrm{SO}_{2}, \mathrm{NO}_{x}$, and PM reduced substantially by $65 \%, 60 \%$, and $72 \%$, respectively (Tang et al., 2019).

Many post-Soviet countries experience similar challenges with industrial pollution, particularly due to their similarities in their emissions permitting systems, poor monitoring and enforcement, systems for environmental payments, and environmental quality standards, which can be traced back to outdated Soviet-era regulations (UNECE, 2009; OECD, 2019).

\subsection{Changes in Meteorology and Effect of the Heating Season}

There are substantial seasonal changes in the temperature in the studied period (March 1May 15) (Table 2). There is a $15^{\circ} \mathrm{C}$ difference: the average temperature was $-2^{\circ} \mathrm{C}$ in the prelockdown period (March 1-April 1, 2020).

Ust-Kamenogorsk is a city with long and cold winters and the period from March to May, is transitional due to rising temperatures and subsequent declining coal usage at heat and power plants and for households. Thus, the end of the "heating season" might affect the levels of pollution in the city. From the summary statistics it can be seen that in the previous years (20162019) average concentration of TSP in April 2-May $15\left(55-82 \mu \mathrm{g} \mathrm{m}^{-3}\right)$ was substantially lower relative to the average values in March 1-April $1\left(107-200 \mu \mathrm{g} \mathrm{m}^{-3}\right)$. It is not surprising that the end of the heating season has a more substantial effect on levels of TSP pollution than a trafficfree environment. Similar trends can be observed for $\mathrm{CO}$. The $\mathrm{NO}_{2}$ and $\mathrm{SO}_{2}$ concentrations were also affected by seasonality but to a lower extent.

Average temperature during the lockdown (April 2-May 15, 2020) was $13^{\circ} \mathrm{C}$, while during the same period in the previous years $(2016-2019)$ it was $8-11^{\circ} \mathrm{C}$ (Table 2). Thus, it could be expected that in the 2020 lockdown period the air quality would be better compared to the previous years. On the other hand, there were lower values of precipitation (it was $0.17 \mathrm{~mm}$ ) during the lockdown period (April 2-May 15, 2020) compared to the same period in the previous years (2016-2019) (it was $0.29-0.5 \mathrm{~mm}$ ). No substantial differences in the wind speed are observed during the lockdown period (April 2-May 15, 2020) compared to the previous years (2016-2019), which was in the range between 2.1-3.55 $\mathrm{m} \mathrm{s}^{-1}$. Relative humidity was $54 \%$ during the lockdown (April 2May 15, 2020) and 60-64\% in the same period of the previous years (2016-2019).

Thus, to address these complex patterns in the data, we utilize the panel dataset and try to capture any seasonal changes on pollutants and also control for weather in different specifications in our regression framework.

\subsection{Regression Results}

The regression results are presented in Table 4. The top panel of Table 4 reports fixed effects coefficients on the COVID-19 lockdown in Ust-Kamenogorsk, and the bottom panel of Table 4 reports fixed effects coefficients with Driscoll-Kraay (DK) standard errors. Columns (1) to (3) report the outcomes for $\mathrm{CO}$ emission, with three model specifications demonstrating robust estimates. The COVID-19 lockdown reduces ambient CO concentrations by 21-23 percent, depending on the model specification. The corresponding models for $\mathrm{NO}_{2}$ that are shown in Columns (4) to (6) demonstrate a decline in ambient $\mathrm{NO}_{2}$ concentrations of 8-9 percent. However, the results are not statistically different from zero in the fixed effects model with Driscoll-Kraay standard errors. Columns (7) to (9) report that COVID-19 lockdown reduces ambient $\mathrm{SO}_{2}$ concentrations by 7-10 percent, though the results are not statistically significant in the fixed effects model with DK standard errors. The last Columns (10) to (12) show that lockdown leads to an increase in the ambient TSP concentrations by 13-21 percent, depending on the model specification. The results are overall significant across both fixed-effects models.

Overall, our analysis by pollutant type shows that the lockdown does not affect pollutants uniformly. Specifically, the effect of the lockdown, and of the transportation sector per se, is negative for $\mathrm{CO}$ and $\mathrm{NO}_{2}$, but it is positive for TSP and $\mathrm{SO}_{2}$. The results are in line with other studies 


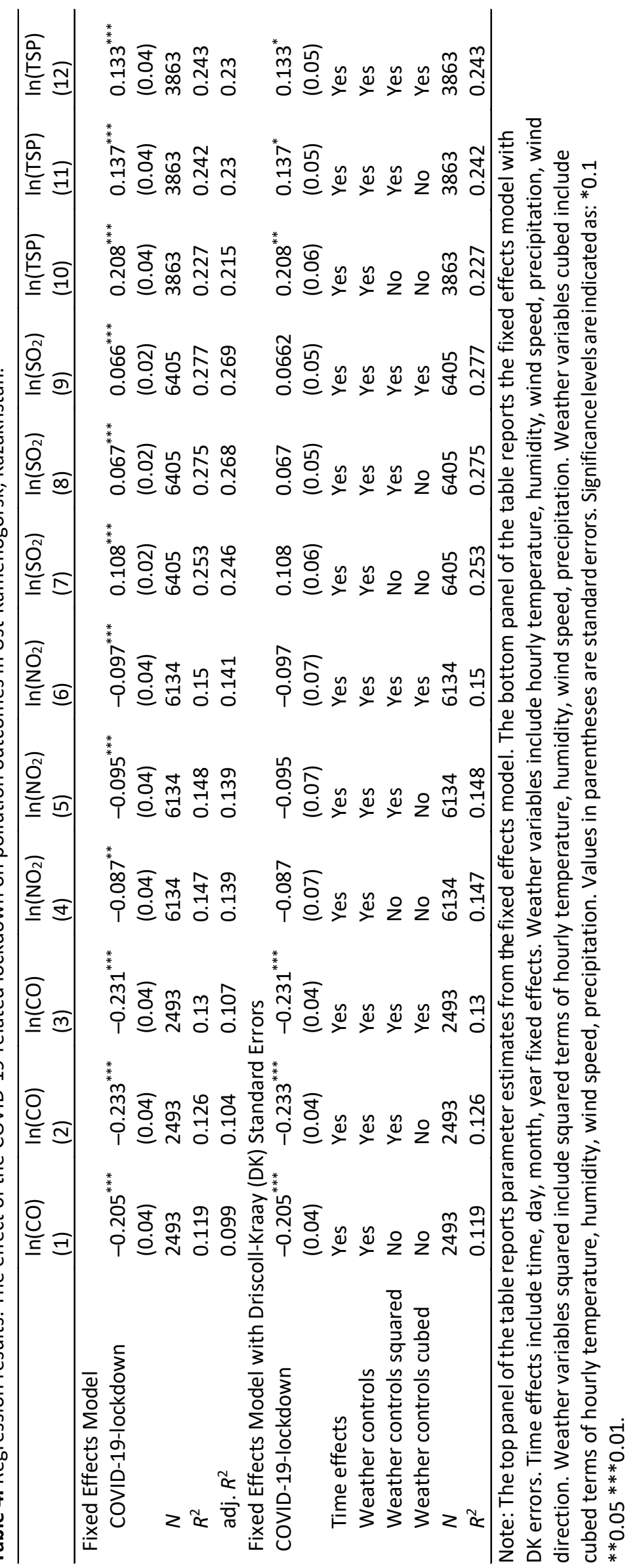


that demonstrate a reduction in $\mathrm{NO}_{2}$ (Almond et al., 2020; Tobías et al., 2020). No substantial changes (or slight increase) in $\mathrm{SO}_{2}$ were observed in India (Sharma et al., 2020), Kazakhstan (Kerimray et al., 2020), and in North China (Shi and Brasseur, 2020) which could be due to the absence of restrictions on coal power plants and coal-burning for heating.

In contrast to other studies, $\mathrm{PM}_{2.5}$ and $\mathrm{PM}_{10}$ data were not available for Ust-Kamenogorsk, but TSP data was employed instead. Since the $\mathrm{PM}_{10}$ and $\mathrm{PM}_{2.5}$ are fractions of TSP, to contrast our results, we compare changes in TSP with changes in $\mathrm{PM}_{10}$ and $\mathrm{PM}_{2.5}$ from other studies. These studies show varying effects of lockdown on $\mathrm{PM}_{10}$ and $\mathrm{PM}_{2.5}$. The $\mathrm{PM}_{10}$ and $\mathrm{PM}_{2.5}$ concentrations reduced by 20-50\% (Kerimray et al., 2020; Mahato et al., 2020; Sharma et al., 2020; Tobías et al., 2020), with substantial reductions in Delhi and six other regions in India (Mahato et al., 2020; Sharma et al., 2020). In India, restrictions were applied to both the transport and industrial sectors. While in Ust-Kamenogorsk, the largest industrial emitters, such as Kazzink LLP and coal power plants, continued their operation. Ust-Kamenogorsk has a bigger industrial base compared to the transport fleet; therefore, the impact of transport on TSP emissions could be small.

\section{CONCLUSIONS}

This article estimates the effects of COVID-19 related lockdown measures in Ust-Kamenogorsk, the most heavily polluted city of Kazakhstan and one of the global hotspots of $\mathrm{SO}_{2}$ pollution. Data with measurements four times per day from five monitoring stations across the city and the weather data were studied for the period from March 1 to May 15 in 2016-2020.

Many areas of the world reported air quality improvements during COVID-19 related lockdown measures. Ust-Kamenogorsk suffers from extremely high pollution levels and COVID-19 related lockdown measures, aimed mostly at the transportation sector, did not improve the air quality. The location of several stationary emission sources in the city, such as large metallurgical complexes and coal-fired CHPs without end-of-pipe emission controls complicates the structure of emissions sources.

Extreme levels of $\mathrm{SO}_{2}$ pollution were detected in the city during lockdown (April 2-May 15, 2020) as the average concentration of $\mathrm{SO}_{2}$ was $88 \mu \mathrm{g} \mathrm{m}^{-3}$. There was not even a single day during the studied period at which the WHO daily limit for $\mathrm{SO}_{2}$ was met.

Future studies should conduct appropriate emissions inventory and source-apportionment of major air pollutants. Stringent emissions standards for coal-fired power plants should be adopted in Kazakhstan to stimulate wide adoption of the end-of-pipe emissions controls. Our regression analysis, which is robust to spatial and temporal dependencies in the data, showed that the lockdown has a significant negative effect on $\mathrm{CO}$, no significant effect on $\mathrm{NO}_{2}$ and $\mathrm{SO}_{2}$, but a positive significant effect on TSP.

This paper's findings suggest that the transport sector might not be the driving force behind air pollution in the city, and thus, policies should be aimed at the industrial sector instead.

Limitations of this study must be noted. In this study boundary layer height and temperature inversions were not accounted for due to the absence of data. Future studies need to study the impact of such conditions on changes in air quality.

\section{DECLARATION OF COMPETING INTEREST}

No potential conflict of interest was reported by the authors. The authors declare that they have no known competing financial interests or personal relationships that could have appeared to influence the work reported in this paper.

\section{ACKNOWLEDGMENT}

The work of Daulet Assanov was supported by the grant from the Ministry of Education and Science of the Republic of Kazakhstan № AP08053440 “Research of emissions major sources of harmful substances into atmospheric air of Ust-Kamenogorsk with the cause identification of high hydrogen sulfide content". The work of Aiymgul Kerimray was supported by the Postdoctoral 
Fellowship Program of Al-Farabi Kazakh National University. We are grateful to the Kazhydromet for providing the data on pollutant concentrations. We are grateful to the two anonymous reviewers, Dana Bazarkulova for the suggestions and comments to the paper. We are grateful to Nurgisa Rametov for preparing the map of Ust-Kamenogorsk.

\section{SUPPLEMENTARY MATERIAL}

Supplementary material for this article can be found in the online version at https://doi. org/10.4209/aaqr.200663

\section{REFERENCES}

Almond, D., Du, X., Zhang, S. (2020). Ambiguous Pollution Response to COVID-19 in China (No. w27086). National Bureau of Economic Research, Cambridge, MA. https://doi.org/10.3386/w2 7086

Ash'aari, Z.H., Aris, A.Z., Ezani, E., Ahmad Kamal, N.I., Jaafar, N., Jahaya, J.N., Manan, S.A., Umar Saifuddin, M.F. (2020). Spatiotemporal variations and contributing factors of air pollutant concentrations in Malaysia during movement control order due to pandemic COVID-19. Aerosol Air Qual. Res. 20, 2047-2061. https://doi.org/10.4209/aaqr.2020.06.0334

Bedi, J.S., Dhaka, P., Vijay, D., Aulakh, R.S., Gill, J.P.S. (2020). Assessment of air quality changes in the four metropolitan cities of India during COVID-19 pandemic lockdown. Aerosol Air Qual. Res. 20, 2062-2070. https://doi.org/10.4209/aaqr.2020.05.0209

Chen, Q.X., Huang, C.L., Yuan, Y., Tan, H.P. (2020). Influence of COVID-19 event on air quality and their association in mainland China. Aerosol Air Qual. Res. 20, 1541-1551. https://doi.org/10. 4209/aaqr.2020.05.0224

Chen, Y., Whalley, A. (2012). Green infrastructure: The effects of urban rail transit on air quality. Am. Econ. J. 4, 58-97. https://doi.org/10.1257/pol.4.1.58

Darynova, Z., Amouei Torkmahalleh, M., Abdrakhmanov, T., Sabyrzhan, S., Sagynov, S., Hopke, P.K., Kushta, J. (2020). SO $\mathrm{SO}_{2}$ and $\mathrm{HCHO}$ over the major cities of Kazakhstan from 2005 to 2016: influence of political, economic and industrial changes. Sci. Rep. 10, 12635. https://doi.org/10. 1038/s41598-020-69344-w

Davis, L.W. (2008). The effect of driving restrictions on air quality in Mexico city. J. Polit. Econ. 116, 38-81. https://doi.org/10.1086/529398

Department of Ecology of East-Kazakhstan Region (2016). The conclusion of the state environmental review on the "Draft of standards for maximum permissible emissions of harmful (polluting) substances into the atmosphere for Sogrinsk CHP for 2016-2020". No. KZ11VCY00073315 dated July 29, 2016.

Department of Ecology of East-Kazakhstan Region (2017). The conclusion of the state environmental review on the "Draft standards for maximum permissible emissions of harmful substances into the atmosphere for the UK MK Kazzinc LLP for 2018-2022". No. KZ19VCY00100331 dated October 3, 2017.

Department of Ecology of East-Kazakhstan Region (2018). The conclusion of the state environmental review on the "Draft of standards for maximum permissible emissions of harmful (polluting) substances into the atmosphere for Ust-Kamenogorsk CHP". No. KZ25VCY00138538 dated December 6, 2018.

Ecoservice-S (2019). Adjustment of environmental quality targets of the East-Kazakhstan region. European Environment Agency (EEA) (2020). Sulphur dioxide $\left(\mathrm{SO}_{2}\right)$ emissions. https://www. eea.europa.eu/data-and-maps/indicators/eea-32-sulphur-dioxide-so2-emissions-1 (accessed 9 June 9 2020).

Greenpeace (2019). Global $\mathrm{SO}_{2}$ emission hotspot database. https://www.greenpeace.org/ nternational/press-release/23819/global-so2-air-pollution-hotspots-ranked-by-greenpeace-a nalysis/ (accessed 1 August 2020).

Guerreiro, C.B.B., Foltescu, V., de Leeuw, F. (2014). Air quality status and trends in Europe. Atmos. Environ. 98, 376-384. https://doi.org/10.1016/j.atmosenv.2014.09.017

He, G., Pan, Y., Tanaka, T. (2020). The short-term impacts of COVID-19 lockdown on urban air 
pollution in China. Nat. Sustain. 3, 1005-1011. https://doi.org/10.1038/s41893-020-0581-y

Helm, D. (2020). The environmental impacts of the coronavirus. Environ. Resour. Econ. 76, 2138. https://doi.org/10.1007/s10640-020-00426-z

Hoechle, D. (2007). Robust standard errors for panel regressions with cross-sectional dependence. Stata J. 7, 281-312. https://doi.org/10.1177/1536867X0700700301

Driscoll, J.C., Kraay, A.C. (1998). Consistent covariance matrix estimation with spatially dependent panel data. Rev. Econ. Stat. 80, 549-560. https://doi.org/10.1162/003465398557825

IQAir (2020). World's most polluted countries 2020 (PM2.5) https://www.iqair.com/world-mostpolluted-countries (accessed 17 June 2021).

Kazhydromet (2020). Information bulletins on the state of the environment of the Republic of Kazakhstan. https://www.kazhydromet.kz/uploads/calendar/1/year_file/31-01-20-byulleten_ 2019-god_rus.pdf?cache=1584006519 (accessed 1 August, 2020).

Kenessary, D., Kenessary, A., Adilgireiuly, Z., Akzholova, N., Erzhanova, A., Dosmukhametov, A., Syzdykov, D., Masoud, A.R., Saliev, T. (2019). Air pollution in Kazakhstan and its health risk assessment. Ann. Global Health 85, 133. https://doi.org/10.5334/aogh.2535

Kerimray, A., Baimatova, N., Ibragimova, O.P., Bukenov, B., Kenessov, B., Plotitsyn, P., Karaca, F. (2020). Assessing air quality changes in large cities during COVID-19 lockdowns: The impacts of traffic-free urban conditions in Almaty, Kazakhstan. Sci. Total Environ. 730, 139179. https://doi.org/10.1016/j.scitotenv.2020.139179

Kerimray, A., Bakdolotov, A., Sarbassov, Y., Inglezakis, V., Poulopoulos, S. (2018). Air pollution in Astana: Analysis of recent trends and air quality monitoring system. Mater. Today:. Proc. 5, 22749-22758. https://doi.org/10.1016/j.matpr.2018.07.086

Li, J., Tartarini, F. (2020). Changes in air quality during the COVID-19 lockdown in Singapore and associations with human mobility trends. Aerosol Air Qual. Res. 20, 1748-1758. https://doi.org/10.4209/aaqr.2020.06.0303

Lin, W., Xu, X., Ma, Z., Zhao, H., Liu, X., Wang, Y. (2012). Characteristics and recent trends of sulfur dioxide at urban, rural, and background sites in North China: Effectiveness of control measures. J. Environ. Sci. 24, 34-49. https://doi.org/10.1016/S1001-0742(11)60727-4

Mahato, S., Pal, S., Ghosh, K.G. (2020). Effect of lockdown amid COVID-19 pandemic on air quality of the megacity Delhi, India. Sci. Total Environ. 730, 139086. https://doi.org/10.1016/j.scitote nv.2020.139086

Organisation for Economic Co-operation and Development (OECD) (2019). Addressing Industrial Air Pollution in Kazakhstan. Reforming Environmental Payments Policy Guidelines. https://www.oecd.org/environment/addressing-industrial-air-pollution-in-kazakhstan-0e04ea 86-en.htm (accessed 17 June 2020).

Order of the Minister of National Economy of the Republic of Kazakhstan (2015). Hygienic Standards for Atmospheric Air in Urban and Rural Settlements. http://adilet.zan.kz/rus/docs/V 1500011036 (accessed 15 August 2020).

Pan, X. (2011). Sulfur Oxides: Sources, Exposures and Health Effects, in: Nriagu, J.O. (Ed.), Encyclopedia of Environmental Health, Elsevier, Burlington, pp. 290-296. https://doi.org/10.1 016/B978-0-444-52272-6.00069-6

Şahin, Ü.A. (2020). The effects of COVID-19 measures on air pollutant concentrations at urban and traffic sites in Istanbul. Aerosol Air Qual. Res. 20, 1874-1885. https://doi.org/10.4209/aa qr.2020.05.0239

Sharma, S., Zhang, M., Anshika, Gao, J., Zhang, H., Kota, S.H. (2020). Effect of restricted emissions during COVID-19 on air quality in India. Sci. Total Environ. 728, 138878. https://doi.org/10.101 6/j.scitotenv.2020.138878

Shi, X., Brasseur, G.P. (2020). The response in air quality to the reduction of Chinese economic activities during the COVID-19 outbreak. Geophys. Res. Lett. 47, e2020GL088070. https://doi.org/10.1029/2020GL088070

Tang, L., Qu, J., Mi, Z., Bo, X., Chang, X., Anadon, L.D., Wang, S., Xue, X., Li, S., Wang, X., Zhao, X. (2019). Substantial emission reductions from Chinese power plants after the introduction of ultra-low emissions standards. Nat. Energy 4, 929-938. https://doi.org/10.1038/s41560-0190468-1

Tobías, A., Carnerero, C., Reche, C., Massagué, J., Via, M., Minguillón, M.C., Alastuey, A., Querol, $X$. (2020). Changes in air quality during the lockdown in Barcelona (Spain) one month into the 
SARS-CoV-2 epidemic. Sci. Total Environ. 726, 138540. https://doi.org/10.1016/j.scitotenv.202 0.138540

U.S. Environmental Protection Agency (U.S. EPA) (2019). Air Emissions Inventories, Air Pollutant Emissions Trends Data, table Average Annual Emissions. https://www.epa.gov/air-emissionsinventories/air-pollutant-emissions-trends-data (accessed 9 June 2020).

UNECE (2009). Environmental performance reviews: second review. Kyrgyzstan. United Nations, New York. http://www.unece.org/environmental-policy/environmental-performance-reviews/ enveprpublications/environmental-performance-reviews/2009/2nd-environmental-performa nce-review-of-kyrgyzstan/docs.html (accessed 15 August 2020).

Wang, Z., Zheng, F., Zhang, W., Wang, S. (2018). Analysis of $\mathrm{SO}_{2}$ pollution changes of BeijingTianjin-Hebei region over China based on OMI observations from 2006 to 2017. Adv. Meteorol. 2018, 8746068. https://doi.org/10.1155/2018/8746068

World Health Organization (WHO) (2006). Air Quality Guidelines - Global Update 2005. https://www.euro.who.int/en/health-topics/environment-and-health/air-quality/publication s/pre2009/air-quality-guidelines.-global-update-2005.-particulate-matter,-ozone,-nitrogen-di oxide-and-sulfur-dioxide (accessed 15 June 2020).

Zhao, P., Tuygun, G.T., Li, B., Liu, J., Yuan, L., Luo, Y., Xiao, H., Zhou, Y. (2019). The effect of environmental regulations on air quality: A long-term trend analysis of $\mathrm{SO}_{2}$ and $\mathrm{NO}_{2}$ in the largest urban agglomeration in southwest China. Atmos. Pollut. Res. 10, 2030-2039. https://doi.org/10.1016/j.apr.2019.09.011 